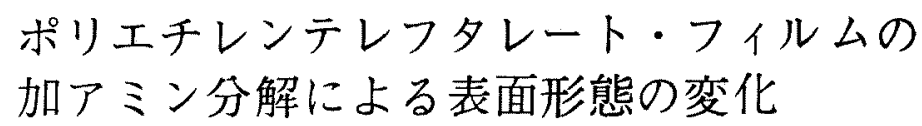

群馬大学工学部関根哲 山本雄三 㐬藤安史・木下茂武

\title{
CHANGE IN THE SURFACE MORPHOLOGY OF POLY(ETHYLENE TEREPHTHALATE) FILMS BY AMINOLYSIS
}

\author{
By Tetsu Sekine, Yuzo Yamamoto, Yasushi Saito and Shigetake Kinoshita
}

(Faculty of Engineering, Gunma University, Kiryu City, Japan)

\begin{abstract}
Morphological changes of poly(ethylene terephthalate) (PET) film during degradation in an aqueous ethylamine solution at room temperature were examined using photomicrographies. Sample films used in this study were prepared by stretching and annealing the melt quenched amorphous PET film, as shown schematically in Fig. 1.

The more crystalline and highly oriented the specimen is, the lower is the rate of the weight loss during the aminolysis (Fig. 2-4). This indicate that ethylamine selectively etches the amorphous PET chains.

In the case of non-crystalline film (Fig. 5), the etching pattern was sensitive to the chain orientation anisotropy. For the crystalline films (Fig. 6-8), the etching pattern mainly occurs perpendicularly to the draw direction in accordance with the formation of folded-chain crystals during annealing.

The changes of weight loss and of the melting behavior are in accordance with the results from the microscopy.
\end{abstract}

(Received November 28, 1974)

\section{1. 緒言}

ポリエチレンテレフタレート(PET)の加アミン分解 や加水分解杜試料の表面加ら進行し，その作用は次第に 内部におよび非晶部の分子鎖を分解溶出させ，結晶を紐 分化し分離させてゆく。従来から，このような作用は， PET緎維の改質に広用されており，またフィルム表面 などのエッチングや維满造の研究手段として用いられ ている ${ }^{1,2)}$ 。前報に拟い筆者らは，ヶエチルアミンに よる軽度のフミン分解をおこなって，延伸PETフィル ムの熱収綰に扔ける結晶相の形態变化を観察している そのさいは，検鏡武料の作製を目的として，エッチング バターンが鮮明にみられる程度の作用に留めたが，PET の加アミン分解はその結晶化度によっ下相違し，無定形 試料で約 1 時間，結晶化試料ではその 10 倍の時間を要 した。このため筆者らは，履楚の異った各種のPETフ イルムをつくって，それぞれの結晶化度ないし配向の程 度によってフミン分解がどのように進行するかを比較的
長時間にわたって検討した。えられた結果のうちで，分 解作用が内部の維組織を変化させる有様については， ひきつづき別報りで述べることにして，本報ては，PET フィルム表面の形態变化に関するアミンの分解の時間拣 存性を主として報告する。

モノェチルフミンによるPETの分解過程は，糸を用 いたばあいその細構造と関係づけて栗田 ${ }^{6)}$ によって詳 しく研究されて㧍り，初期段階で非晶領域が選択的に牙 解され，その後に速度のおそい結晶領域の分解がつうく ことが明らかにされている。そしてFarrow ら゙が前 にメチルてミンを用いたとき非晶と結晶との分離が困難で あったとするのに対し，このばあいは電子線が通過可能 にまで分解された分散試料を観察して，PETの末延伸

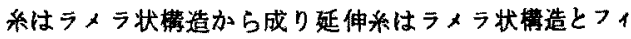
ブリル状楧造とからなることを推論している。筆者らのお。 こなったPETフィルムに対するDSC, WAXS, SAXS および顕鏡観察などの一速の実験結果も栗田の見解を 支持するものであり，本報で以下に述べるような，重重 
椇失および表面エッチング・ハターンに示されるミク口 ン・ォーダーの敏細組械との時間的变化についてもこの 䊗の䫅向はやはり詡められた。

\section{2. 実㷂}

\section{1 試 料}

実慗に用いたフィルムは市服（帝人製）の 2 轴延伸ポ リエチレン・テレフタレート (PET)フィルムで, 厚さ 150 ミクロン $(\mu), \mathrm{X}$ 線結晶化度 $\left(\alpha_{c}\right)$ 約 $40 \%$, 結晶是 向関数 $(f)$ は雨軸方向とも約 0.7 である。このフィルム を出発物（記号B）にして，炏のような種々の展璴をもつ 試料を作成し，加フミン分解鬽理に供した。本報で使用 した試料の記号およびその作成の嗤過を四 1 に示した。

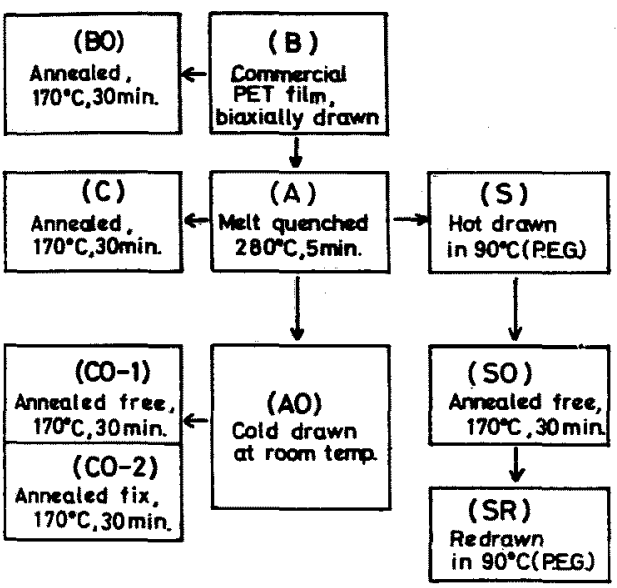

Fig. 1 Deformation and heat treatment steps used in the preparation of experimental PET films.

（A）急冾 (非晶性未配向) 試料 $\left(\alpha_{c} \approx 0, f \approx 0\right.$ ),

(AO) 命延伸 (非晶性西向) 試料 $\left(\alpha_{c} \approx 0, f a m o r\right.$ $\approx 0.75$ ),

（S）温延伸 (半結晶性束状配向) 試料 $\left(\alpha_{c} \approx\right.$ 0.1. $f=0.78)$,

(SO) 湿延伸自由熱如理（半結晶性ラォラ状西 向) 試料 $\left(\alpha_{c}=0.28, f=0.82\right)$ ，

(C) 熱処理（結晶性未挋向）試料 $\left(\alpha_{c}=0.3\right.$, $f \approx 0$ ),

(CO-1) 冾延伸自由熱処理（結晶性鬼向）試料 $\left(\alpha_{c}=0.35, f=0.83\right)$,

(CO-2) 冾延伸定長熱処理（結晶性眍向）試料 $\left(\alpha_{c}=0.38, f=0.85\right)$,

(BO) 二軸延伸自由熱观理（結晶性二軸邑向） 試料 $\left(\alpha_{c}=0.45, f=0.76,0.77\right)$.

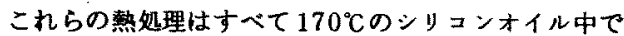
30 分間抎こなった。熟処理後試料は合水中で急冷した。

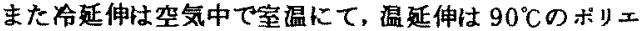
チレン・グリコール (PEG) 浴中で行いその啳洽水中て 急命した。延伸試料は延伸直後 15 分以上延伸機につけ たまま放厧し固定をはかった。

\section{2 加アミン分解処理}

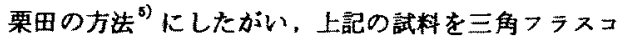

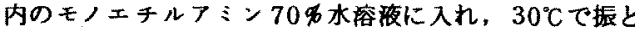
うしながら処理した。所定の時間に達したならば取り出 して水拉よ゙゙ィタノールで洗った倦、エチレングリコー ル中に入れて $60^{\circ} \mathrm{C} て ゙ 24$ 時間抽出した。抽出を䅂った試 料は室温て真空乾燥した。減量は処理前後の重量変化加 ら求めた。なお試料 BOについては，Farrowらの方 法でメチルアミン 20 力水客葆による分解观理も陚みて比 整した。

常温におけるPETのメチルアミンによる反応では分 子鎖の切断が

$$
\longrightarrow \mathrm{COOCH}_{2} \mathrm{CH}_{2} \sim+\mathrm{NH}_{2} \mathrm{CH}_{2} \mathrm{CH}_{3}
$$

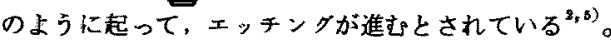

\section{3 表面形憗の舅察}

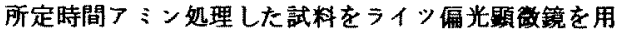
いて倍事 100 倍で観察した。また日本電子製 JEM-7型 電子顕敬鏡を用いて表面形態を，酢酸セルロ一ズ膜でレ プリカをとりクロム蒸着して観測した。

\section{4 熱測定}

前項上同様の試料をはさみで切断し $4 \mathrm{mg}$ を来めて， Perkin Elmer 社製 DSC - IB 型示差走查熱量計でサ 一モグラムを得た。界温速度は $16^{\circ} \mathrm{C} / \mathrm{min}$ ，窒素気流中 で研定した。

\section{5 広角X線回折}

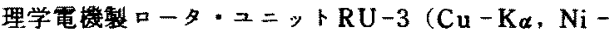
filter）衣使用し，出力 $45 \mathrm{kV}, 70 \mathrm{~mA}$ で喟定した。X 線結晶化度 $\left(\alpha_{c}\right)$ の算出は次のようにした。すなわち。

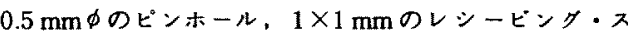
リットを用い，X線ビームに対し華直で每分 77 回転て 試料を回転しながら、シンチレーション・カウンターで $2 \theta=10^{\circ} \sim 36^{\circ}$ の回折強度曲線を求める。この强度曲線 に空気散乱の補正を行い，干涉性回折の総面積に対する 結晶性回折の面耫比を定めて，これを結晶化度 $\alpha_{c}$ の值 とした。このとき非晶性回折強度としてはmelt quench した試料 $\mathrm{A} の$ 回折強度加ら空気散乱を除いたものを用 た。

なお 2.1 試料の項で付記した配向関数 $f$ の值は I05配 向関数である。これは Dumbletonの方法 ${ }^{7 \sim 9}$ に従って， 
$\overline{1} 05$ 回折ピークの積分巾 $H$ を求め， $f=(180-H) / 180$ として算出した。この場合バック・グラウンドの補正と $\overline{1} 05$ と $\overline{0} 24$ ピークとの分離は前報" と同槏に行った。

\section{3. 結果および考察}

\section{1 アミン分解による重量変化}

ひととの試料のはじめの重量を $w_{0}$ 所定時間 フミン処理 した後の重量を $w(\mathrm{t})$ として, その不溶解残留量(insol一 uble fraction) $x(\mathrm{t})$ あるい梳解による减量 (weight loss）1-x(t)を百分率 (务) で

$$
x(\mathrm{t})=w(\mathrm{t}) / w_{0} \quad(\times 100)
$$

のように定義する。 $x(t)$ は時刻 $t$ の経過につれて，(a) 物質内へアミンの抬散・浸透過程で亭留し、(b) 非昆領 域の分解溶出，(c) 結晶领域の分解路出，(d) 微結晶な いし粉末状粇子の䧹脱などで減少し，また (e) 溶出物の 付着などがあれば增加する。したがって增堿の速度定数 をレ招よびれとして、形式的には

$$
d x / d t=-\Sigma \lambda_{i} x_{i}^{m_{i}}+\Sigma \nu_{i}\left(1-x_{j}\right)^{n_{i}}
$$

とおける。簢単に分解が単一の機構で行われて $\nu=0$, $m=1$ のばあいには，時刻 $t$ まての残留量 $x(\mathrm{t})$ は

$$
x(\mathrm{t})=x_{0} \mathrm{e}^{-\lambda t}
$$

のように滅少してゆく。そこで各試料の残留量の対数を 処理時間に対してプロットすると，因2〜4のとおりで ある。図2は末熱処理試料 (A，AO，S)であり，図 3,4 はいずれも熱処理試料 (C, SO， CO-1，-2，BO）であ って，平均的な减量速度は前者が後者より1桁程度大き いことがわかる。いいかえ扎ばフミン分解におけす重量 の平均寿命は非晶質PETでは短汃く，結晶質P PETでは

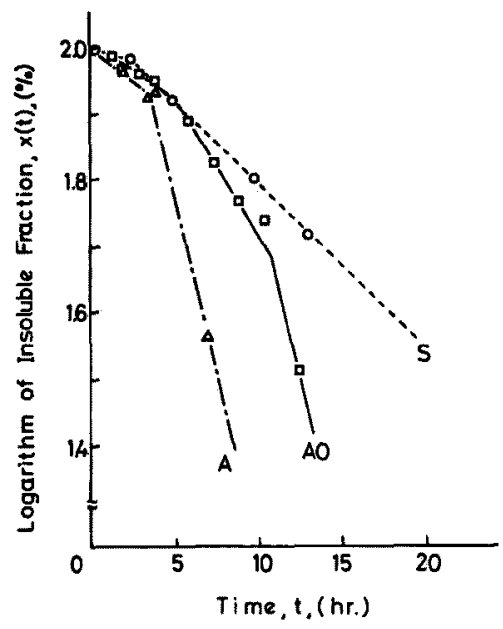

Fig. 2 Logarithm of insoluble fraction of sample A, $\mathrm{AO}, \mathrm{S}$ vs. degradation time.
おそく 10 倍ほど長い。

（1）非晶性 PETフィルム

試料ごとの特徽をみると，非晶未配向物 $\mathrm{A}$ ，その命延 伸物 $\mathrm{AOO}$ ，また温延伸物 Sは，この先出牌に娍量がより 急速である。表 1 はこれらの試料の分解過程を，处理時 間 $t(\mathrm{hr})$ に対方る速度定数 $\lambda(\% / \mathrm{hr}$ ) $)$ 值を用いて比 校したものである。減量の第 1 段階は各試料ともアミン によるPET分子鎖の切断とその客出であろうと思われ る。不溶解残留物の分子量は，渠田に上れば ${ }^{(2)}$ ，試料 $\mathrm{A}$ に相当する非晶末延伸米で 0.5 時間で，試料AOに相当 する延伸系で 2 時間くらいで，はじめの值の $1 / 8$ に低

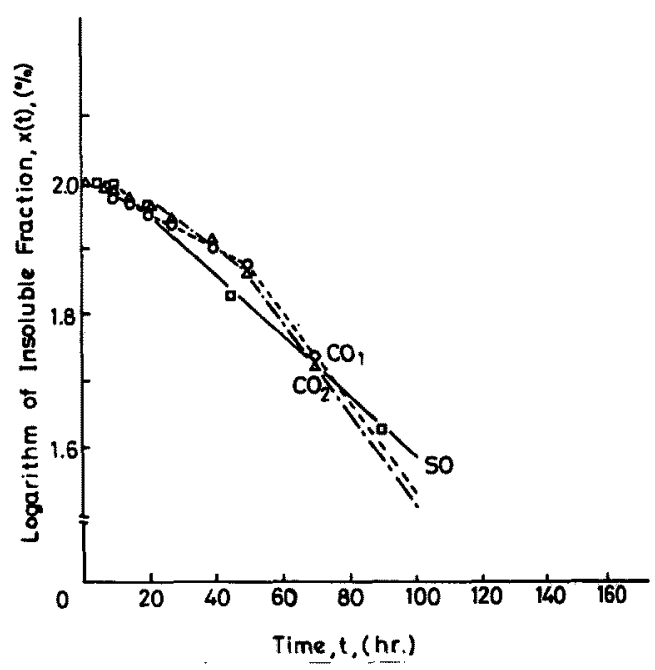

Fig. 3 Logarithm of insoluble fraction of sample SO, $\mathrm{CO}-1, \mathrm{CO}-2$ vs. degradation time.

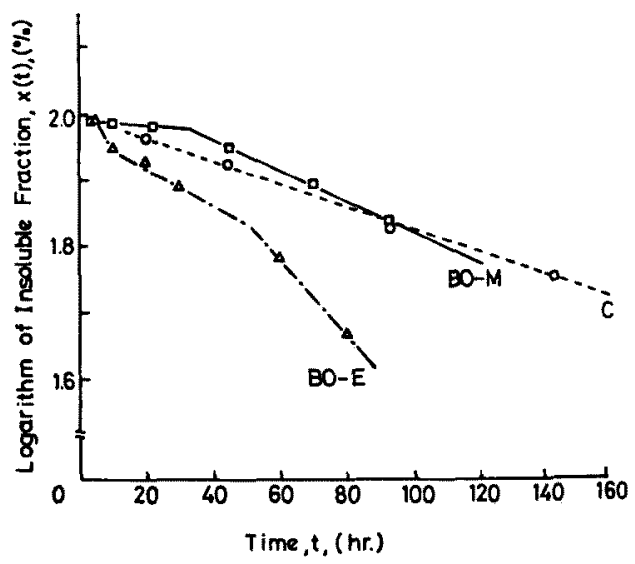

Fig. 4 Logarithm of insoluble fraction of sample $C$, $\mathrm{BO}-\mathrm{E}, \mathrm{BO}-\mathrm{M}$ vs. degradation time. 
Table 1. Changes of the rate of degradation, $\lambda(\% / \mathrm{hr}$.$) ,$ for non-crystalline PET samples during various aminolysis time, $t$ (hr.).

\begin{tabular}{|c|c|}
\hline $\begin{array}{l}\text { non erystalline } \\
\text { PET sample }\end{array}$ & oninolysis time (hr.) \\
\hline $\begin{array}{l}\text { undrawn, A } \\
\text { cold drawn, AO } \\
\text { hot drawn, S }\end{array}$ & $\begin{array}{l}-4.37+27.6 \rightarrow \\
-3.91 \rightarrow-966 \rightarrow-253 \rightarrow-2.3 \rightarrow \\
-161 *-5.75 \rightarrow\end{array}$ \\
\hline
\end{tabular}

下し，それ以授は低下がなく一定值となる。試料 Sの分 子量低下はさらに長時間を要するであろう。釆とフィル ムの試料形状の相连を考虑しても，時間的な頖向は同じ と考えられる。沙少の速度定数についてみると禾のばあ いの方が表1のフィルムのばあいよりも2３倍速い。 これは糸の方が表面抬散効果が大きいためで、フィルム

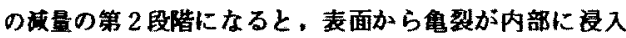
し，系の速度值に近づく。な括系の第 2 段階では速度定 数が第 1 段階より小さくなり，低分子量の結晶が生成し

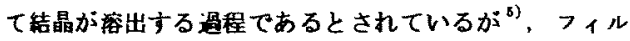
ムではこれに相当するものはみられない。もし低分子の

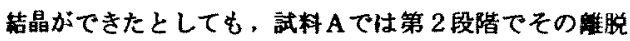

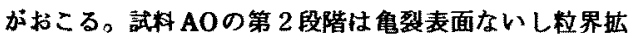
数で境界が容出することによってブロック化が拈こって，

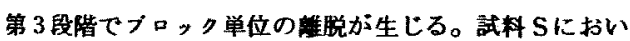
ては、ブロック単位の䑏脱は阻止されて第 2 段㳻が長く 统く。こうして, 非晶性PETフィルムの加アミン分解 では㳊量に関して第 2 段陵以後の速度定数が第 1 段階よ り大きくなるのであろう。

（2）結晶性PETフィルム

つぎに表 2 に熱処理した結晶性PETフィルムの入の 值を示した。試料 SOは 10 時間まで变化なく，以後は非

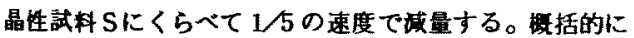
いえば加アミン分解に対する抵抗力は自由熱処理て5 倍 に增大する。同样なことが試枓AOを自由悠好理した試 斗CO-1K对してやはりその第 1 ，第 2 殷階であてはま っているさらに定長热处理試料 $\mathrm{CO}-2$ でも, 試料 $\mathrm{CO}-$ 1 の第 1 段俻の前半の時間で娍量が少くその绻半で大き くなる㑯向があるほが，ほぼ同じ様式に従っている。 ここに現かれる僅かの差は，試料 CO-2の結晶化度と㕵 向とが試枓CO-1よりややまさっていることに因るので あろう。また非晶未纪向試料 $\mathrm{A}$ を熱処理した結晶性の

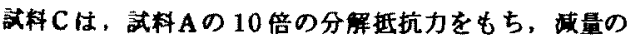
速度定数は 150 時間にわたって一定で武料 Aの $1 / 10$ の 值である。おそらくフミンの結晶留内体磧払散に支同さ れる単一な出過程と思われる。

\section{(3) 二轴逴伸PETフィルム}

Table 2. Changes of the rate of degradation, $\lambda(\% / \mathrm{hr}$.), for crystalline PET samples during various aminolysis time, $t(\mathrm{hr}$.$) .$

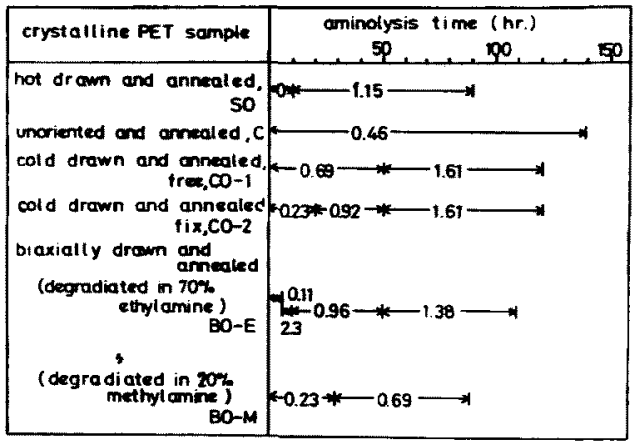

以上の一軸延伸試料にくらべて二軸延伸熱処理試料 BOの減量の仕方は，はじめの遅れ部分を別にすれば。 一軸試料COのそ扎とほぼ同様である。すなかちェチル フミン処理の BO-E試科は 5 時間まで速度定数入の值が 小さく，以後 5 時間 $\lambda$ の大きな值で破量して，10時間 倦は試料 CO-1，-2と平行に経過する。ここで比較のた めに扢るなた チルアミン処理の試料 BOーMをみると 诚量の仕方がBO-E試料とは異っている。メチルフミン がエチルアミンよりも度は小さいが, steric factor が小さく反底速度は8倍である。したがってPET組 の細部まて浸入し易く”，BO-Mでは、初期減量のおく れが現かれない。なお第 1 段階は, 結晶化度の小さい試 料 $\mathrm{CO}-2$ におけるェチルアミン处理と同じ速度で, 第 2 段階はさらに結晶化度の劣る試料 $\mathrm{CO}-1$ のエチルフミン のばおいの初期の速度定数と偶然にも同じ值になってい る。このことは，適当な条件のもとでは，高結晶化度の 試料のみチルアミン分解と低結晶化度の試料のエチルア ミン分解とで、ほほ同程度の效果がえられることを示し ている。

\section{2 表面形䈍の娈化}

(1) 非晶性PETフィルム

非晶性PETフィルムのェチルアミン分解にともなう 表而態の変化を、処理時間に対する影教鏡写真で图 5 に示した。無配向試料 Aは，非晶域分子鎖切断の第 1 段 階 30 分ですでたきな割れ目（数 $10 \mu) か ゙$ 発生して割れ 目に治った容出の形跡が認められる。减量第 2 段階の 5.2 時間で付割れ目内がさらに細分化され数ミクロンの 粒子が連って踓抜している。合延伸試枓AOの時間的変 化は加アミン分解に対する非晶 (四向) PETの典型例と 思われる。末処理物では延伸方向に垂值なっラックが散 
在しているが，30分処理で轵方向に $20 \mu$ 程の平行な龟 裂が現われ、これは end 方向からみるとフィルム表面か ら内部に向って裂けている。この減量第 1 段階は重裂巾 に相当するマクロフィブリル間の非晶城にアミン分子が 表面抬散してPETの非晶分子鎖を切断容出させる過程 であろら。第2段階のはじまる 4.5 時間処理ては，マク ロフィプリルが境界面から溶けで师き，8時間処理の第 2段階末期でフィブリルはレンガ状に割れてその間隔が 著しく拡大している。このことから減量第 2 段階は，フ ミン分子の境界拡散と非晶質への体積圷散とによるPET 分子鎖の切断, 溶出過程と考えられる。このばあいフィ ルムの edge方向からみると表面のレンガ状絴片は境界 が下地から分離して厚さ $5 \mu$, 直径数 $10 \mu$ の円弧状とな っている。11時間処理以上の減量第 3 段階は，このよ うな円硍状細片が単位となって表面から次々に離技する ことが主因である。温延伸試料 Sの処理表面の形態変化 屯，試料AOとほぼ似ている。减量第1段階でマクロフ イプリル化してからレンガ状の割れ目が入る。ただし試 料 Sの方が試料AOより結晶化度がよく非晶分子鎖も密 に搛っていると考えられ，フミン分子の拡散は痋く、レ ンガ状物が表面から内部に向って次第に溶出してゆく第 2 段階が長く持続して, 試料AOにおけるような円弧状 細片単位の離抜は認められない。

（2）結晶性 (未配向) PETフィルム

以上に対比して，熱処理結晶性 PETフィルムのアミ ン処理による形態変化は，各試料について図6〜8に示 したように，いずれも結晶化度の增加を反映して観察に 長時間を要する。極端な例は結晶性未配向試料Cのばあ いで,この滅量は一定速度で 150 時間以上も持続して， アミン分解は結晶内体積拡散による単一過程と推定され たものである。因 6 の顕微鏡写真および图 7 の電子顕微 鏡写真でもこの推定は支持されるが，形態変化からみる と, 溶出は同じバターンの同期的な繰返しで進行してい

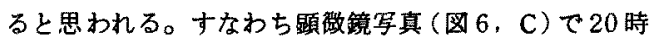

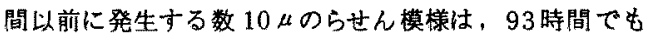
143 時間処理でも同様に現われていて，ときとして同じ 試料の別の場所には長方形模様もみられる。しかもらせ ん模様の焦点深度を潹くすると底がくびれて長方形模様 が存在することが認められる。表面のらせん模様が溶出 すると下地から長方形模様が現われ，それがらせん模様 に変形あるいは成長してまた容出するというパターンを 絽返すのであろう。このようなエッチングパターンの变 化がマミンによるPET分子鎖の切断や低分子量物の結 晶化などとどのように関係するが明らかでない。しか

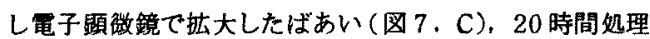
ではらせん氉様の内部は，約 1,000 ̊̊ボーネ状体がお
ぼろげにらせんを画いて連なって数哃状物をつくって いる。溶出が進んだ 143 時間になると巾 $2 \mu$ 程度の带状

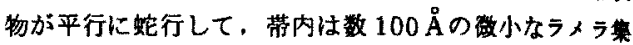
積組織となっている。さらに倍率をあげてみればラィラ 集積組織は $100 \AA ̊$ 程度のラォラの板状の重なりで、これ が綎方向に節理をもって柱状に別れている。そしてその 表面には $100 \AA$ 公らの粉状物が点々と付着している。 おそらくこのような結晶ラィラの原組䄉にもとずいて， 顕饭鏡オーダーの数 $10 \mu$ のらせんあるいは長方形模様が できあがるのであろう。

（3）結晶性（配向）PETフィルム

冷延伸および温延伸試料を熱処理した試料 $\mathrm{CO}-1$ ， CO-2およびSOは，配向組織のため結晶界面にフミン 分子が入りやすく，末配向のC試料にくらべて減量は 2〜3 倍速くなっている。图6の顕鏡写真をみると， SO武料では 10 時間までは減量がないが，5時間好理物 で表面に細かい条線がクロスして甡生している。10時

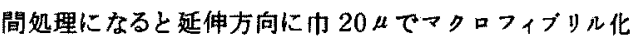
し，フィプリル内はそれに垂直に $1 \mu$ 間隔でひび割れて いる。この段階加ら隇量がはしまって，20時間姤理で はフィブリル内のひび割れが拡大しながらブロック化す るが，表面から奥に入ったところでは細かい割れ目が梁 部に進行する。 80 時間処理になれば部分的にブロック が溶出してそのあとに新しい表面が現われていることが

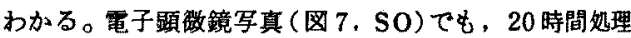
に戈ける配向ラメラ集棈物が，80時間処理では部分的 に溶出している有様が見られる。いっぽう冾延伸物を自 由熱処理したCO-1 試料（图 6, CO-1），定長熱观理 L た CO-2 試料（図6, $\mathrm{CO}-2$ ) は表面の割れ方が温延伸 熱処理の SO陚より不料則てある。そして，アミン処 理の初期の段階で，延伸試料が綎にフィブリル化するの に対して，その熱好理試料は横にびび割れるという一般 的な傾向は， $\mathrm{CO}-1 ， 2$ 試料の方が $\mathrm{SO}$ 試料よりも䫏著 になっている。CO-1と CO-2武料との時間的変化を比 较すると，前者のCO-1はアミン未妱理時に表面みられ る巾数 $10 \mu の$ 横じわが減量第 1 段倩 5 時間処理でたて よこ数ルに細かくひび割れを起こし，それ以後は速度が 2 倍の減量第 2 段階となって 10 時間から 20 時間にわた って数 $10 \mu$ の横長の長方形模様が抬大しつつ，それが 117 時間まで溶出してゆく。この溶出につれて下地から は再び細かい数旧横長のひび割れが現かれる。後者 CO-2の释過もほぼ同様であるが，定長で熟观理されて いるため最初の表面にはところどころ横方向にクラック が入っていてその他の地は全般的にアミンが浸透し篧い。 したがって 5 時間始理までの减量壮CO-1試料よりも㜊 れて，以後は前者の第 2 段階と同し速度て減量し，長方 


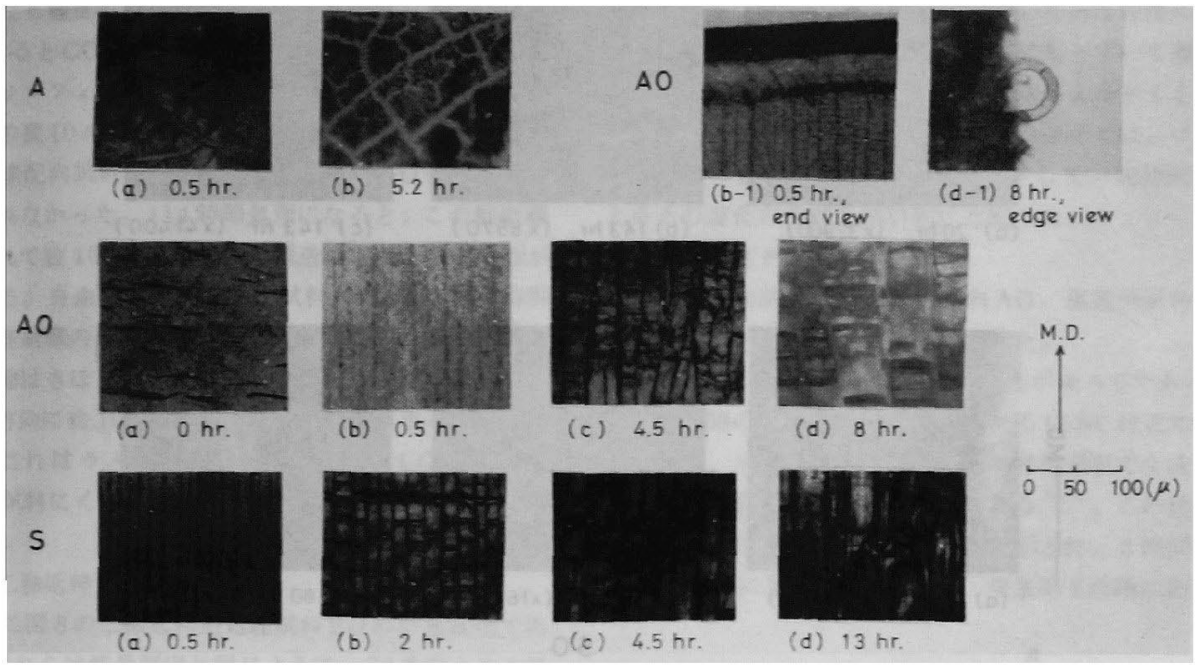

Fig. 5 Microphotographs of non-crystalline PET films degraded for various time. $(\times 260)$.

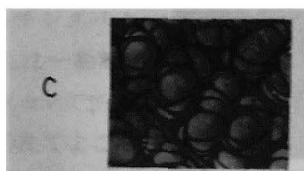

(a) $20 \mathrm{hr}$. (1)

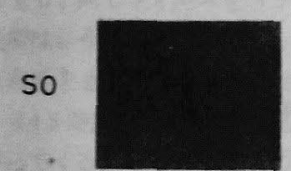

(d) $5 \mathrm{hr}$.

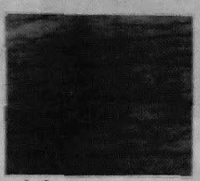

(a) $\mathrm{O} \mathrm{hr}$

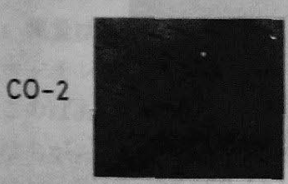

(a) $0 \mathrm{hr}$

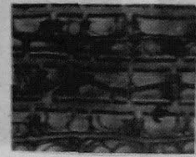

(b) $93 \mathrm{hr} .(2)$

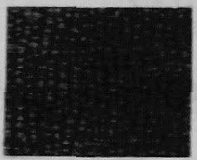

(b) $10 \mathrm{hr}$

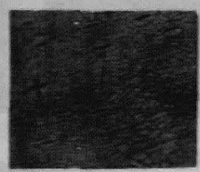

(b) $5 \mathrm{hr}$

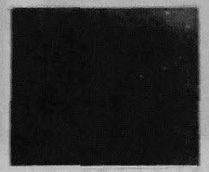

(b) $5 \mathrm{hr}$

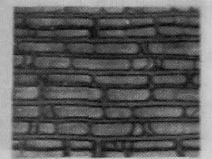

(c) $143 \mathrm{hr}$. (1)

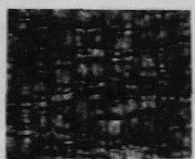

(c) $20 \mathrm{hr}$

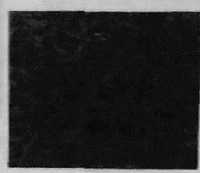

(c) $10 \mathrm{hr}$

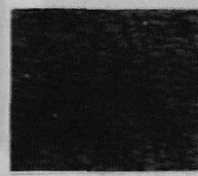

(c) $10 \mathrm{hr}$.

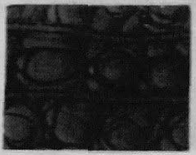

(d) $143 \mathrm{hr}$. (2)

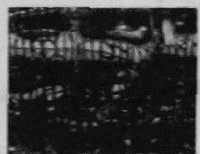

(d) $80 \mathrm{hr}$.

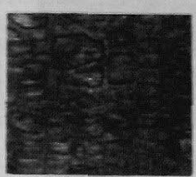

(d) $21 \mathrm{hr}$

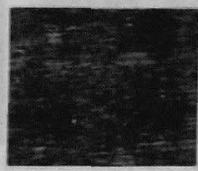

(d) $20 \mathrm{hr}$

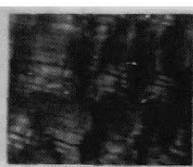

(e) $143 \mathrm{hr}$. (2) in derp focus.

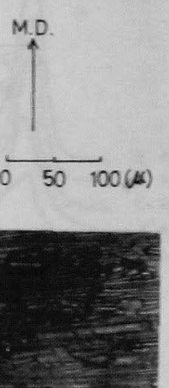

(e) $117 \mathrm{hr}$

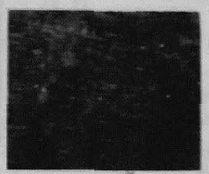

(e) $117 \mathrm{hr}$

Fig. 6 Microphotographs of crystalline PET films degraded for various time. ( 260$)$. 


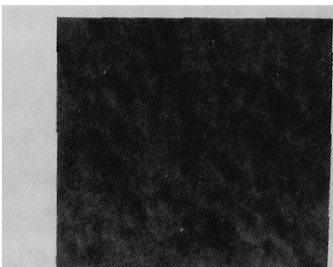

(a) $20 \mathrm{hr} .(\times 32900)$

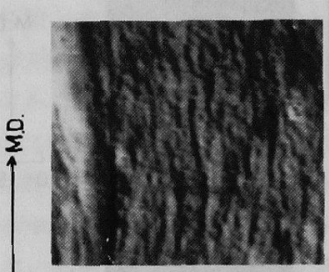

(a) $20 \mathrm{hr}(\times 41400)$

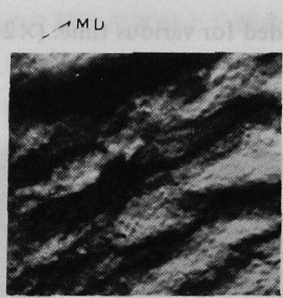

(a) $114 \mathrm{hr} \cdot(\times 41400)$

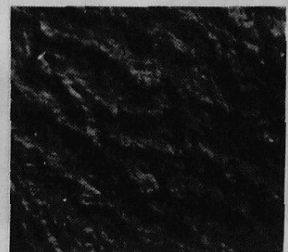

(b) $143 \mathrm{hr} \cdot(\times 8570)$

C

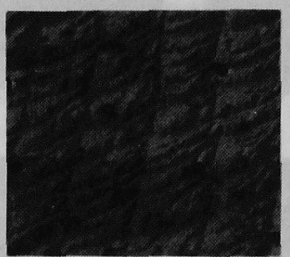

(b) $80 \mathrm{hr} . \quad(\times 16600)$

$\mathrm{SO}$

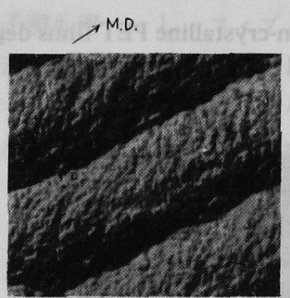

(a) $21 \mathrm{hr} . \quad(\times 41400)$

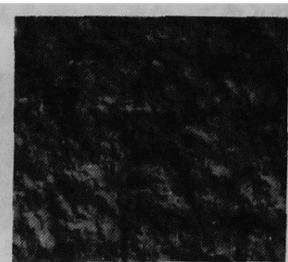

(c) $143 \mathrm{hr}(\times 41400)$

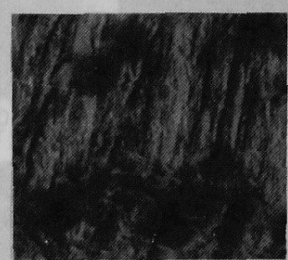

(c) $80 \mathrm{hr}(\times 41400)$

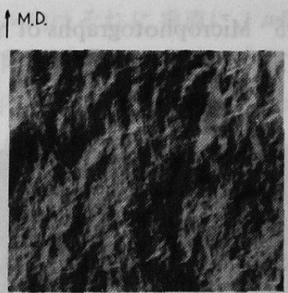

(b) $114 \mathrm{hr} .(\times 41400)$

$$
\text { CO }-1
$$$$
\mathrm{CO}-2
$$

$0^{2} 25005000\left(A^{\circ}\right)(x 41400)$

Fig. 7 Electron micrographs of crystalline PET films degraded for various time.

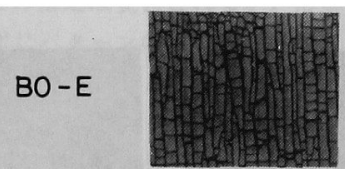

(a) $5 \mathrm{hr}$

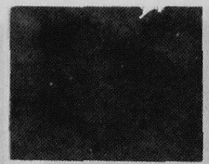

(a) $11 \mathrm{hr}$.

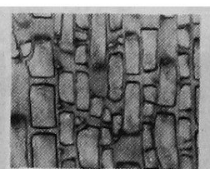

(b) $10 \mathrm{hr}$.

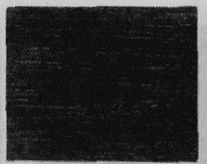

(b) $30 \mathrm{hr}$

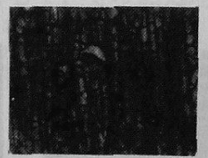

(c) $20 \mathrm{hr}$.

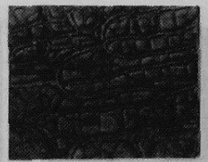

(c) $44 \frac{1}{2} \mathrm{hr}$.

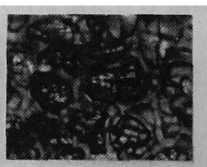

(d) $40 \mathrm{hr}$.

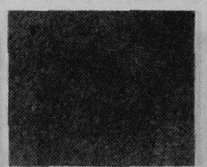

(d) $93 \frac{1}{2} \mathrm{hr}$

\section{$0 \longdiv { 5 0 1 0 0 ( \mu ) }$}

Fig. 8 Microphotographs of biaxially drawn PET films degraded for various time. ( $\times 260)$. 
形のせルの形成と下地のひび割れ模様も同じ形態で幾分

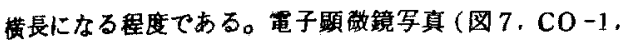
2)でみるとCO-2試料の表面は 21 時閣処理て $5,000 \AA$ 位のミクロフィブリル状の畦組織が現われている。これ

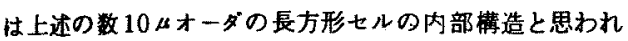
るが，末眍向武料Cや盜延伸熱㚾理試料 SOでは存在が 諗められなかった。114時間処理になると，この睛組織 はこわれて数 $100 \AA ̊ 丿$ の角ばった棈造からなる小さな面が 出ている。自由熱処理のCO-1 試料では同じ 114 時間 処理で唯組䋘のゆがんだ㡾跡が残っており, 数 $100 \AA$ 単 位の表面はさほど鋭くないが，その内部に延伸方向と直 交した方向に約 100 Aの厚さの細い線が密集して見えて いる。これはラメラ厚に相当するもので CO-1試料が C0-2 試料にくらべて fold 晶ができ易いことの結果で あろう。

\section{(4) 二蚞延伸PETフィルム}

つぎに図 8 の二軸延伸熱姏理試料 $\mathrm{BO}$ の形態变化であ るが、これらは減量洞定と同じように、70\%のエチルフ ミン処理試料 BO-Eと20かのメチルアミン処理試料 BOMとを比较しておこなった。通常のBO-E試料は 5 時間 でとつの方に並んだひび割れがおこり，10時間で エッチングバターンが数 $10 \mu$ オーダの長方形セルとなる。 これは一軸延伸の CO-1 試料の 20 時間処理とはぼ同じ ヘターンである。20時間から40 時間になると次第にセ ルのたてよこ比が 1 に近づき，50時間以上ではCO-1 試料の㨔量第 2段階と同様にセルは丸みをおでて溶出が 進行する。同じフィルムをメチルフミン妈理したBO-M 試料では，今度は 11 時間たっても変化が僅かで 30 時間 で方性をもった巾数 $\mu$ 緑かい平行線バターンが現わ れ，44.5時間でそのなかに処々に数 $10 \mu の$ ル模様が 佁がってくる。そしてこれらの平行線やセルは 93.5 時間 の長時間処理になると数んの細かい粒子状に分解されて しま5。眼括的にいって結晶化度の高いBO試料のィチ ルフミン分解の绻段 30 時間以後の形態変化は, 减量の 比方と同様に，結晶化度の低いCO試料でのェチルアミ ン处理における初期段階の分解様式に類似している。

\section{3 アミン分解試料の㷫測定}

前項で幊察されたように，フミン処理の時間経過につ れて，減量は試料廈歴に固有な仕方で段階的に進み，表 面のエッチング・バターンはその段階に応じて変ってゆ く。このばあいの表面形態の変化は，単なる機械的な虽 離とはちがって、試料の内部構造がそのまま露出したも のではない。われわれは、アミン分子が試料の表面ない し境界をへて体稫内に泣散し，PET分子鎖を加了ミン 分解することによってその凝集構造を穴出したり再組䋐 したりした痕跡をみたのである。本報の範用でPETの
加フミン分解現象そのものまで深入りすることはできな いにしても，その再組载の仕方についてある程度の検討 をしておくことは，表面形態の触察にもとずいて履歴の ちがった試料の内部構造の相違を理解しようとするとき 必要なことと思われる。この観点から以下では, アミン 処理試料のDSCサーモグラムを測定して，処理時間に よるその変化の有様を試料別に比較した。

(1) 非昆性PETフィルム

急冷末配向試料 A, 冷延伸試料 $\mathrm{AO}$ ，温延伸試料 $\mathrm{S} の$ サーモグラムをまとめて図 9 に示した。

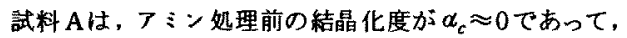
各処理時間のプロフィールに現われる $258^{\circ} \mathrm{C}$ 付近の融解 ピークは，いずれもDSC測定時の昇温過程で生成した

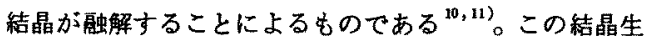
成は $130^{\circ} \mathrm{C}$ 付近にある発熱ピークで示され，3時間処理 までは顥著に鋭くでているが，減量第2段階にあたる
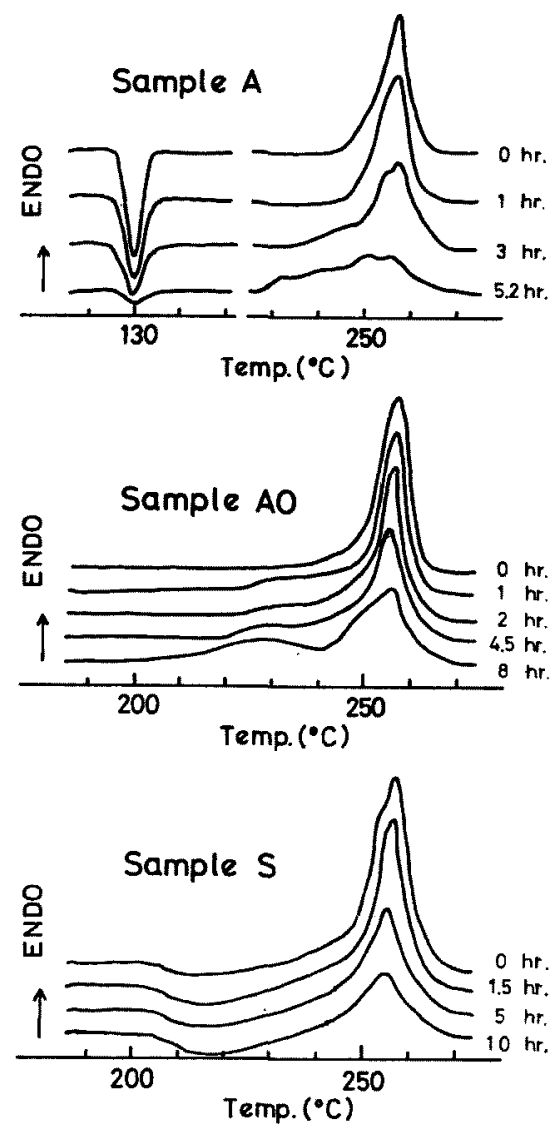

Fig. 9 DSC thermograms of sample A, AO, S degraded for various time. 
5.2 時間処理になるとかなり减少している。後述するよ うに試料 $\mathrm{A}$ の第 2 段階ではフミン処理中に結晶化が進行 していて(図 12)，残った非晶鎖がDSC 測定時に僅か に結晶化するのであるう。フミン処理によってできる結 晶は，非晶鎖の切断による緩和で㤥が発生する分子量の 劣ったものであり，それが長時間処理で故粒化すること は表面観測の結果（図 5，A）で認められていたが，5.2 時間処理物の螱解ピークのブロード化にこのことが見わ れている。

試料AOのサーモグラムでは，はじめ $(0 \mathrm{hr}$.$) に 257.3^{\circ} \mathrm{C}$ にあった䖪解ピークが，隇量第 1 段階のおわる 4.5 時間 で $255.3^{\circ} \mathrm{C}$ ，第 2 段階末期の 8 時間で $253.6^{\circ} \mathrm{C}$ と処理が 進むにつれて低温側にずれている。またこのピーク前の 琚のひろがりが 1 時間処理から4.5時間にかけて目立っ てきて，8時蘭処理では二重ピークを示している。ここ で末処理物のサーモダムが比較的単純なのは，金緝ら が考えているよらに冷延伸が高倍率で行われているため， 延伸による熱力学的安定度を異にした領域の発生が鎖状 分子の函度の配向によって妨げられているからであるう。 延伸倍被が小さいと $100^{\circ} \mathrm{C}$ 付近からは cold crystallizationが, $130^{\circ} \mathrm{C}$ 付近からは premelt crystallizationが開始して登熱側にふふれを生じ, 融解ピーク温度も やや減少する。もしアミン処理によって配向が乱れるなら ばサーモクラムにこのような傾向が現われる筈であるが， われわれのフィルム試料 AOC゙は後述の図12に示すよう に，処理時闒が長くなるとむしろ結晶配向は向上して， サーモグラムも低延伸とは異っている。アミン好理が進 むと主融点が低下することは，来田がのべているとおりり， アミド基の混入, 結晶界面でのアミド基の增加, 結晶寸 法の減少などに因るものと思われる。また裾のひろがり から低温ピークができる原因も，切断された末端にアミ

ド基をもつ短い分子鎖がアミン処理中に低嘱点の小さい 結晶を生成しているからであろう。娍量第 3 段階ではこ の小結晶粒が割れ目でつくられ，表面から円弧状細片を 離抜させる作用をするのかもしれない。

冷延伸に対して温延伸試料 Sでは，融解ピーク温度は 初めの $257.2^{\circ} \mathrm{C}$ から減量第 2 段目の 5 時間処理で $254.8^{\circ} \mathrm{C}$, 10 時間処理では $253.8^{\circ} \mathrm{C}$ と AO同様に低下するが，ピー クの裙のひろがりは少なく特に $213^{\circ} \mathrm{C}$ を心としたブロ ードな発熱ビークが出現する点が違っている。未処理 (0hr.)のばあい，主融解ピークの低温正にショルダー が出ているが，これは油林ら ${ }^{12)}$ がPETの $80^{\circ} \mathrm{C}$ 温延伸米 について主融解の高温ピーク割合いが延伸倍率とともに 低下し，低温ピークのそれが增大することから，前者は DSC 昇温過程で結晶化した foldが，後者は延伸時に生 成する束状晶が，それぞれ㔀解するものと推定したこと
に対応した現象と考えられる。アミン処理が進んだ段階 では暻解ピークはプロートとなって，この区别はつかな い。また処理時間の経過につれて試料 Sでは, 試料 $\mathrm{AO}$ で認め難い発熱ピークがペースライン方向に広がってい る。このことは，陚料 Sの方が結晶化度もその配向も比 較的よいのにアミン処理中に試料AOの結晶化度が速く 增加する(图 12)こと，減量も表面形態の変化も試料 $\mathrm{S}$ の方が遅いことに関連していると思われる。すなわち試 料 Sではアミンによって分子鎖が切断され需みなどが除 去される機会が少なく，処理中には再組織化が完了しな いで，DSC測定の界温過程中に $213^{\circ} \mathrm{C}$ を心とした温 度域で再組䅧化，再結晶化が可能となるのであるう。

（2）結㫬性 (未配向) PETフィルム

試料 C は，急冷試料 A $170^{\circ} \mathrm{C} 30$ 分熱姏理してえた 結晶性未配向フィルムで、アミン処理時間とともにその サーモクラムは四10のように変化する。190ㄷ付近の 吸熱ピークは熱処理のときに再組織された ${ }^{13,11}$ 結晶の融 解を示し, 途中のプロフィールは虽解部分が昇温中に再 結晶化する程度に依存して ${ }^{15)} ， 260^{\circ} \mathrm{C}$ 付近は主融解ビー クである。罒からわかるように処理時間が長くなると， はじめに存在した再組織された結晶は量が咸少し、アミ ン処理中にはおそらく再結晶化も進んで，その結果とし て舅温時の再結晶化の影䡬が少なくなり，230 $\mathrm{C}$ 付近に も発熱ビークが現かれてくる。また主融点も93時間処 妈理までは低下気味である。143時間のサーモグラムは， 熱処理試料よりもむしろメルトから等温結晶化でつくら

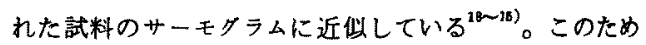
主融点も再び上后に転ずるのであろう。すなわち長時間 フミン処理では，不完全な小さな結晶は溶出し残ったも のが秩序のよい大さな fold 晶に再組織されることを示し， 表面形態の観察とも一致している。

（3）結晶性 (配向) PETフィルム

試料 SO， CO-1，CO-2のアミン処理に対する廿一 モグラムの変化を图 10 に示した。いずれす熱処理温度 $170^{\circ} \mathrm{C}$ 対応する吸熱ピークが $190^{\circ} \mathrm{C}$ 付近に出ている。 これは未配向結晶Cのばあいより小さいが，試料 SOて は, 配向性(図 12)のよいCO-1より大きく，配向性の むっともよいCO-2が最小である。初期の减量はこの低 温吸熱ピークが大きいほど速くなる傎向がある。 $260^{\circ} \mathrm{C}$

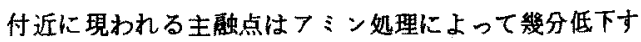
る。またこの主どークのひろがりはSOにくらべてCO-1， -2陚料が狒くなっている。CO-1，-2が結晶化度（图 12)が高くフミン処理中に低融点變結晶の生成量が少な いことによるのであろら。アミン妈理による再組織化を 反映する $230^{\circ} \mathrm{C}$ 付近の発熱ピークは SO試料が最大でて ミンで炀断された分子鎖の年温過程中に結晶化する量の 

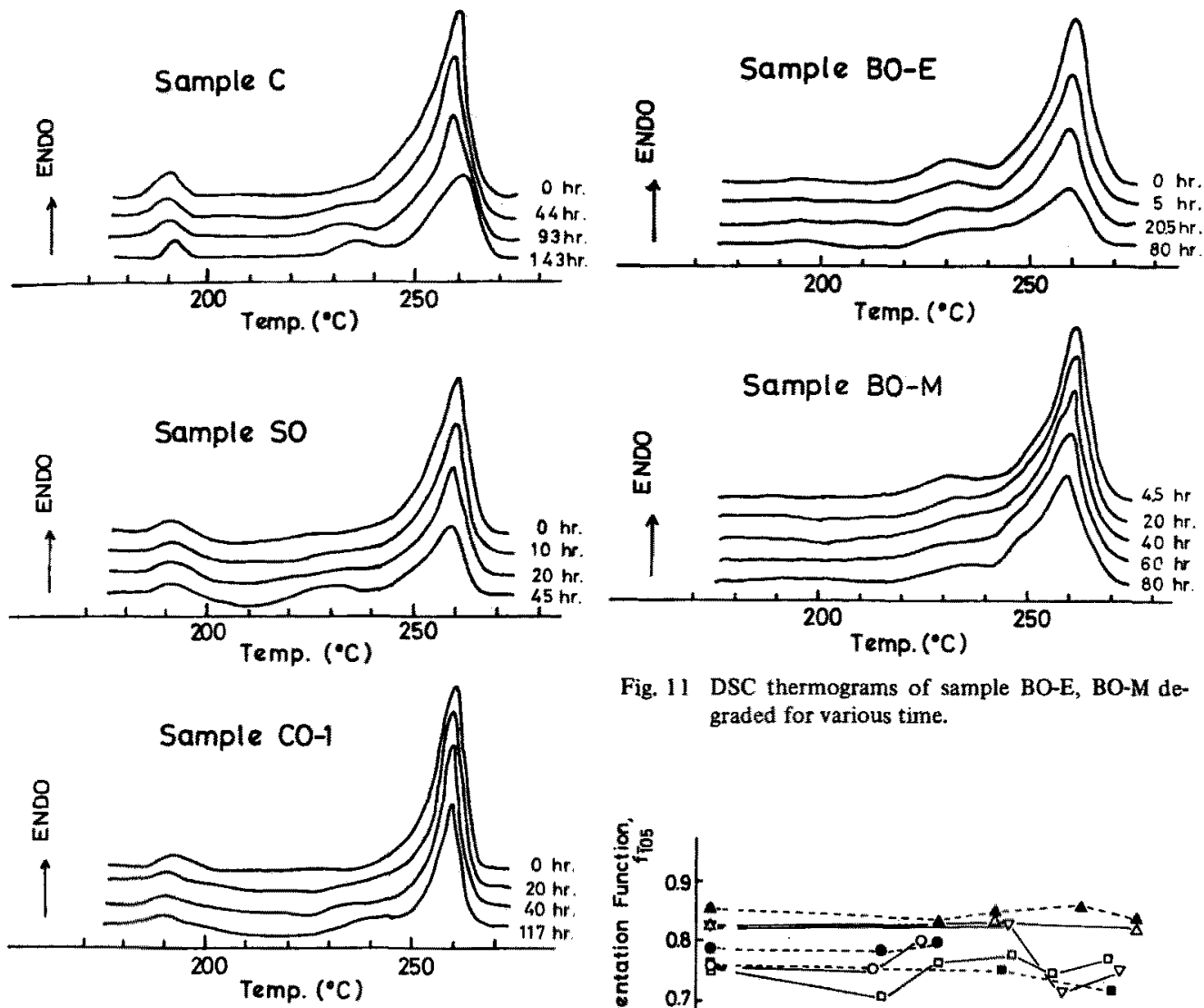

Fig. 11 DSC thermograms of sample BO-E, BO-M degraded for various time.
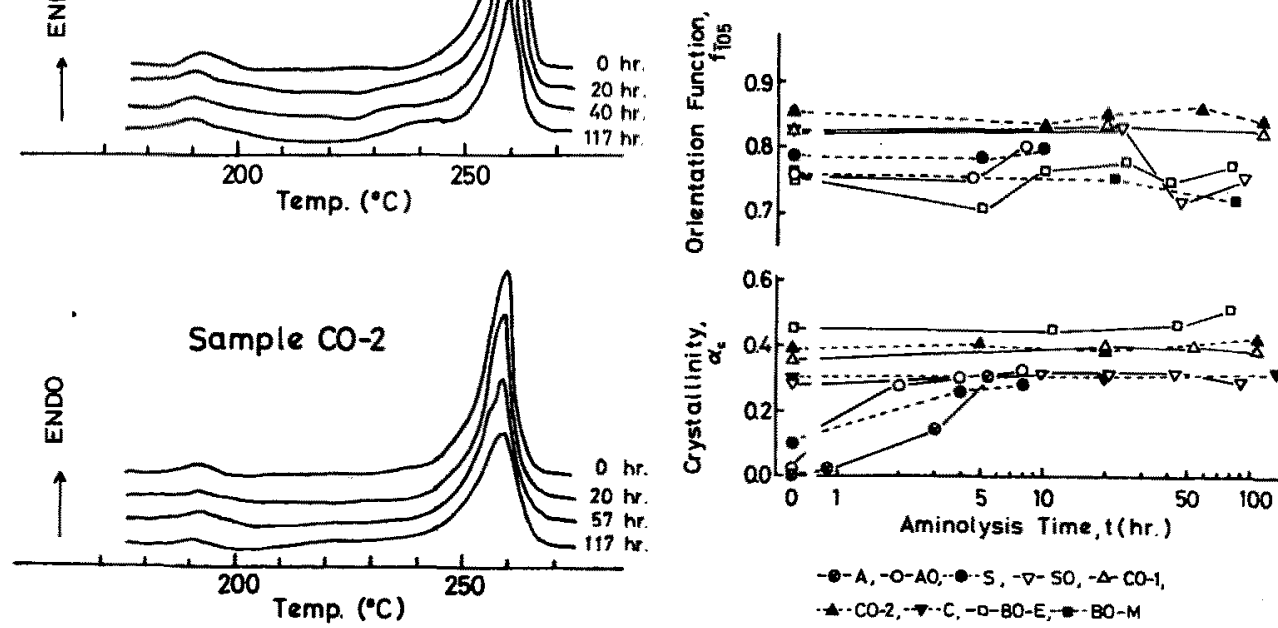

Fig. 10 DSC thermograms of sample $C, S O, C O-1$, CO-2 degraded for various time.

多いことがわかる。しかしこのばあいも观理時間が長く かると、それが察出するか結晶化してしまって，DSC 界温で忙再結晶の量が減少して二重ビークを形成する。 自由熱处理のCO - 1 試料と定長熱越理のCO-2 試料它く

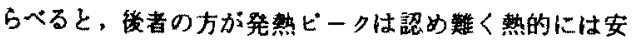

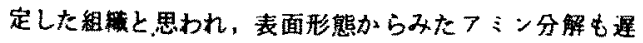

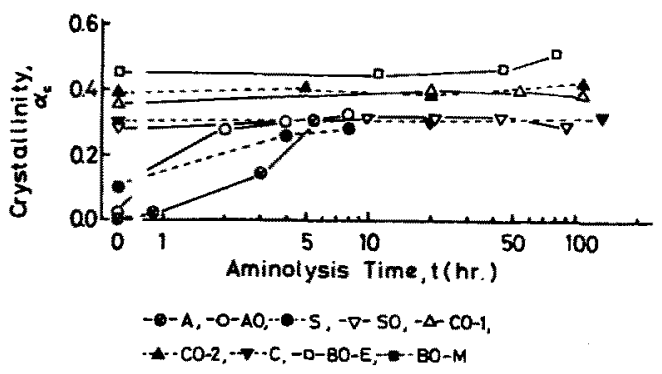

Fig. 12 Changes of orientation function and crystallinity by aminolysis.

くなっている。

(4) 二靼延伸PETフィルム

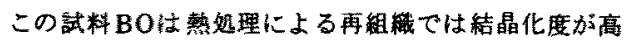
く（四 12）比较的大きなサイスの結昆が生成するため， 网11に示すようにそのサーモクラムは，213ํ付近に 熱好理温度に对底した吸整ピーク有している。フミン 
処理時間が長くなると、このサイズの結晶が破䧇され， 低融点砤結晶の生成がおこり吸熱ピークは先化して主融 解ピークの裾とつながる。そして减量第 2 段階では主融 点が降下する。またサーモグラムの経時变化はェチルフ ミン処理の BO-E 試料にくらべて濃度の低いメチルアミ ン処理の BO-M試料の方が遅れる。表面の観測結果と 同様に, BO-Mの 40 時間くらいが BO-Eの 5 時間以 内のものに相当している。

以上各種試料のアミン処理後のDSCサーもタラムを 比較して昇温前の状熊が知られ，それによれば加フミン 分解で切断されたPET分子は，一部は溶出し，残った ものは処理時間に対応した被細組織の再編成を促進させ ていることがわかる。特に非晶性試料では，分子鎖の繁 張の高いものから $\mathrm{AO}>\mathrm{S}>\mathrm{A}$ の順に一層速く結晶化度を 增大させ，結晶性試料では，熱妈理で生成した結晶部分 が，結晶配向の低いもの加 $\mathrm{C}>\mathrm{SO}>\mathrm{CO}-1>\mathrm{CO}-2$ の 順により多くの量が破壊されてゆくことが推定される。 アミン処理によって生じる減量と表面形的との試料に固 有な変化も，このような政細組織の生成と破境とのかね 合いを主因とした編成替えによって発現するものであり， これについては次節でまとめる。

\section{4. 結語}

延伸，熱処理など履歴を翼にした各種のPETフィル ムを作成して，配向や結晶化度などの相遑が微細構造の 形成とどのように関係するかを検討する目的で, 本報で は70\%エチルアミン水溶液によるPETの加アミン分解 を㧍こない，その進行につれて現われる表面形態の経時 变化を観察した。图1に示した供試試料のうち，急冷試 料 $\mathrm{A}$, 冷延伸試料 $\mathrm{AO}$, 温延伸試料 S U DSC 熱測定やX 線測定からみて非晶性に属し，それぞれの熱妱理物 C， $\mathrm{CO}-1 ，-2, \mathrm{SO}$ 扔よび二軸惩伸熱姏理試料 $\mathrm{BO}$ は結晶 性であるそして各試料をアミン処理したとき，それらの 配向関数 $f$ ，結晶化度 $\alpha_{c}$ は処理時間に対して図 $120 よ$ らに変化してゆく。すなわち $f$ の值は，非晶性配向試料 ではほぼ一定か減量末期の数時間观理ではわずかに增加 し，結晶性のものではほぼ一定か数 10 時間後にわずか に减少する。また $\alpha_{c}$ の值は非晶性のばあい减量初期の数 時間内に増加して一定値に近づき，結晶性試料では減量 末期まで 100 時間以上の長時間にわたってほぼ一定値を 保っている。

この結晶相の変化に対する定量的な考察は别に報告す ることにしで，以上で明らかになった表面形態の加ア ミン分解による変化について本報の観察結果をまとめる と次のとおりである。

(1) 非晶性試料
アミン処理によって，非晶領域に入ったアミンがPET 分子銷を切断し，緊張のとれたところからら結晶化が進む。 その初期段階では，配向にしたがって試料Aではランタ

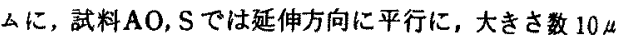
の重裂状エッチング・ヘターンが発生し，その境界面か らの䜌やかな溶出（速度定数 $\lambda \approx 3 \sim 5 \% / \mathrm{hr}$.)をともな いながら，刍裂がブロック状に割れる。後段においては プロック内の結晶化による再組織が完了するにつれて試

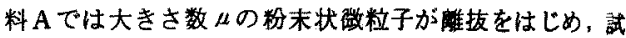
料 AOでは巾と直径とが数 $10 \mu$ ，厚さが数 $\mu$ の円弧状結 晶片が単位となって表面から脱落するようになって，減 量が速くなる $(\lambda \approx 25 \sim 27 \% / \mathrm{hr}$.)。試料 S では未姏理 時の結晶化度が比較的大きく再編成による結晶化度の変 化が少ないため。ブロック境界の溶出量が増すのみで結 晶片の離抜はおこらない。

(2) 結晶性試料

結晶相へのアミン分子の体積厸散でPET分子鎖は表 面から内部に向って加アミン分解され，減量からみを結 晶相の分解抵抗力は非晶相の䄪 10 倍である。無配向試 料Cのエッチング・バーンは結晶相の微細組絨を舆型的

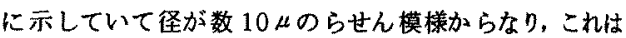
初め $1,000 \AA ̊$ 程度のボール状棈造が渦状に集ってっくら

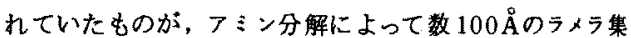
䅡組織に編成替えされて表面から徐々に（ג=0.46\% hr.)溶出する。また同じ結晶相でも，配向物の熱処理効 果は、エッチング・バターンの亀裂が延伸方向に垂直に 数 巾に細かくび゙割れることに現われる。これは熱处 理による fold 晶の形成によるものであり，ての集皘ラォ ラ組織は無配向 C試料にくらべて維密であり初期の減量 は停滞する。しかし刍裂が应大する段階では，配向組絨 の結晶界面にアミン分子が入り易く减量の速度定数は C の2〜3倍となる。このばあい配向と結晶化度の小さな so, $\mathrm{CO}-1, \mathrm{CO}-2$ の順に，より速く表面の㪟細ブロ， クが溶出し下地から新しいひび割れが発生し，再組梓さ れた新しい面には大ささ数 $100 \AA ̊ 丿$ の，後者の試料淁と鋭 利なライラ組織が現われてくる。

(3) 結昆性二軸延伸試料

試料 $\mathrm{BO}-\mathrm{E} は$ はチルアミン処理のばあいで, 初期减量 が大きく，龟裂が比較的深く一方向にそろったものとな る。後段では一軸延伸のCO-1，-2と似た速度定数で诚 量寸るが，エッチング・パターンは比較的大きく䋖撗同

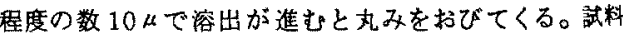
BO-Mは低濃度のィチルフミン処理であって，フミン分 子の浸透の容易さを反映して細かいメッチンダ・゙ー ンが現われる。しかしェチルフミン処理にくらべて镹時 間たってもその变化はゆるやかである。 
(付記) 本報の一部は第 22 回高分子学会年次大会 (1973 年5月, 京都) で発表した。

\section{文哭}

1）たとえば山渏，䨳波：䄉学読，30，T 485 (1974)

2）たとえばA. Miyagi, B. Wunderlich:J. Polymer Sci., Polymer phys. ed., 10, 2073, 2085 (1972)

3）大矢，山本，齐蒌，木下：鐵学誌,投稿中

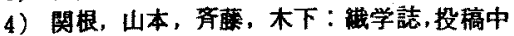

5) 栗田: 高化, 26, 511 (1969)

6) G. Farrow, D.A. S. Ravens, I. M. Ward: Polymer, 3, 17 (1962)
7) J.H. Dumbleton, B. B. Bowles: $J$. Polymer Sci., A-2, 4, 951 (1966)

8) J.H. Dumbleton: J. Polymer Sci., A-2, 7. 667 (1969)

9) J.H.Dumbleton: Polymer, 10,539 (1969)

10）栗山, 富坂, 白慗：高化, 21，584 (1964)

11）金綱, 前田：工化, 69, 1784 (1966)

12) 油林, 折戸, 山田:工化, 69, 1798 (1966)

13）池田，三石：高化，24，378（1967），池田：高 化, 25. 87 (1968)

14) R. C. Roberts: Polymer, 10, 113, 117 (1969)

15) G. E. Sweet, J.P.Bell: J. Polymer Sci., A-2, 10, 1273 (1972)

\title{
ナイロン 6 湿熱法二軸延伸フィルムの 機械的性質と分子配向挙動*
}

\author{
京都工芸織䧽 大学樴維学部 \\ 京都大学農学部 \\ 松本喜代一・黒木俊之 \\ 今村力造**
}

\section{MECHANICAL PROPERTIES AND MOLECULAR ORIENTATION BEHAVIOR OF THE BIAXIALLY STRETCHED NYLON-6 FILMS PREPARED BY WET-PROCESS*}

By Kiyoichi Matsumoto, Toshiyuki Kuroki and Rikizō Imamura* *

(Faculty of Textile Science, Kyoto University of Industrial Arts and Textile Fibers, Sakyo-ku, Kyoto, Japan)

This paper reports on the mechanical properties and behavior of molecular orientation of the Nylon-6 films by means of the uniaxial and biaxial stretching by wet-process in a hot-water bath.

Unoriented low crystalline Nylon-6 film T-die extruded with a thickness of ca. $200 \mu$ was stretched at constant rate of $400 \% / \mathrm{min}$ in a recirculating hot water at $70^{\circ} \mathrm{C}$ by various methods using a filmstretcher; i.e. uniaxial stretching under free width and/or constant width, and simultaneous biaxial stretching. The molecular orientation was studied by both measurements of birefringence for a tilted specimen and $x$-ray diffraction. The mechanical properties of the stretched films such as tensile strength, elongation at break, Young's modulus and $\mathrm{F}_{5}$ value were measured at $20{ }^{\circ} \mathrm{C}$ under $65 \%$ R.H. using an Autograph tensile tester. The dynamic viscoelasticity, i.e. the temperature dependencies of dynamic loss modulus $E^{*}$ were measured at $100 \mathrm{~Hz}$ using a Viscoelastic Junior Spectrometer.

The following results were obtained;

(1) The characteristics of stretched films prepared by wet-process were noted that lower Young's modulus,

*この報文を「フィルムの二軸延伸に関する研究（第 17 報). Studies on the Biaxial Stretching of Films. (part 17)」とする。

**現在の府属; 京都大学费学部 (京都市左京区北白川追分町) Present adress; Faculty of Agriculture, Kyoto University, Sakyō-ku, Kyoto, Japan) 